\title{
Wood Dust in Furniture Manufacturing: An Exposure Determinant Study in Ağrı City
}

\author{
Mobilya İmalatında Ahşap Tozu: Ağrı İlinde Maruziyet Belirleme Çalışması \\ Pınar BAYKAN ${ }^{1}$, Ebru SENEMTAŞI ÜNAL ${ }^{2}$
}

\begin{abstract}
Wood dust exposed during furniture manufacturing processes causes a variety of health problems. The aim of this study is to determine the respirable and inhalable dust exposure of the employees in small-scale furniture workshops located in Ağrı Organised Industrial Zone. For this purpose, the amount of dust exposure in the working environment was measured and the results were compared with the limit values in national and international legislation. Five furniture carpentry workshops in Ağrı Industrial Zone employing less than 10 workers constituted the universe of the study. A total of 22 people work in five workplaces. A total of 15 employees, 3 from each workshop, participated in the study. In this study, "MDHS 14/3: Gravimetric analysis and sampling method of respirable and inhalable dusts" was used for dust sampling. In the study, 30 respirable dust samples and 5 inhalable(total) dust samples were obtanied at 5 workplaces. Based on these measurement results, a daily TWA was calculated for each employee according to the TS EN 689 standard. The results were compared with the values in the national and international standards. It was concluded that the exposed values for dust concentration obtained from only one workplace were below the national and international limit values. It has been observed that a large part of both respirable and inhalable dust exposure values in workplaces exceeded the limit values. Practices and regulations such as tax reductions, incentives and projects that will contribute to the fight against dust in small-scale enterprises should be made.
\end{abstract}

Keywords: Gravimetric analysis, Inhalable dust, Limit values, Occupational health and safety

\section{ÖZ}

Mobilya üretim süreçlerinde maruz kalınan ahşap tozu, çeşitli sağlık sorunlarına neden olmaktadır. Bu çalışmanın amacı Ağrı Organize Sanayi Bölgesinde bulunan küçük ölçekli mobilya atölyelerinde çalışanların solunabilir ve toplam toz maruziyetlerinin belirlenmesidir. Bu amaçla çalışma ortamında maruz kalınan toz miktarı ölçülmüş ve sonuçlar ulusal ve uluslararası mevzuatta yer alan sınır değerler ile karşılaştırılmıştır. Araştırmanın evrenini Ağrı Organize Sanayi Bölgesi'nde 10'dan az işçi çalıştıran beş mobilya marangozhanesi oluşturmuştur. Beş işyerinde toplam 22 kişi çalışmaktadır. Çalışmaya her atölyeden 3 olmak üzere toplam 15 çalışan katılmıştır. Bu çalışmada, toz örneklemesi için "MDHS 14/3: Solunabilir ve solunabilir tozların gravimetrik analizi ve örnekleme yöntemi" kullanılmıştır. Çalışmada 5 işyerinde 30 adet solunabilir toz örneği ve 5 adet toplam toz örneği alınmıştır. Bu ölçüm sonuçlarına göre TS EN 689 standardına göre her çalışan için günlük TWA hesaplanmıştır. Sonuçlar ulusal ve uluslararası standartlardaki değerlerle karşılaştırılmıştır. Sadece bir işyerinden elde edilen toz konsantrasyonu için maruz kalınan değerlerin ulusal ve uluslararası sınır değerlerin altında olduğu sonucuna varılmıştır. İşyerlerinde hem solunabilir hem de toplam solunabilir toz maruziyet değerlerinin büyük bir kısmının sınır değerleri aştığ gözlemlenmiştir. Küçük ölçekli işletmelerde tozla mücadeleye katkı sağlayacak vergi indirimleri, teşvikler ve projeler gibi uygulama ve düzenlemeler yapilmalidir.

Anahtar kelimeler: Gravimetrik analiz, Solunabilir toz, Sınır değerler, İş sağlığı ve güvenliği

This study was supported by the MYO.19.003 code project by the Scientific and Technological Research Council of A ğr İbrahim Çeçen University (BAP). Ăgrt İbrahim Çeçen University Scientific Research Ethics Committee and the study was allowed with the decision dated 25.02 .2021 and numbered 46

${ }^{1}$ Assist. Prof., Pınar BAYKAN, Occupational Health and Safety, Ağrı İbrahim Çeçen University, Department of Occupational Healthand Safety, pbaykan@agri.edu.tr, ORCID: 0000-0001-5279-3872

${ }^{2}$ Assist. Prof., Ebru SENEMTAŞI ÜNAL, Occupational Health and Safety, Ağrı İbrahim Çeçen University, Department of Electronics and Automation, esenemtasi@agri.edu.tr, ORCID: 0000-0002-8530-9423

Corresponding Author:

e-mail:
Pınar BAYKAN

pbaykan@agri.edu.tr
Geliş Tarihi / Received: 02.07.2021

Kabul Tarihi/Accepted: 01.12.2021 


\section{INTRODUCTION}

The industrialization and the increase in technology in the world, with the variety of risk factors that adversely affect the health and safety of employees in working environments is also increasing. The variety of risk factors also increases the occupational risks faced by employees. The furniture manufacturing sector has also been affected by these developments. Furniture manufacturing is included in the "C Manufacturing" section of the Workplace Dangerous Classes Communiqué on Occupational Health and Safety - Workplace Dangerous Classes. Furniture manufacturing activities are classified as dangerous; it consists of shaping and processing wooden materials and furnishing some furniture. Apart from these activities, painting, polishing and varnishing of furniture are under a different code in the very dangerous class. For this reason, the risk factors faced by the employees in the working environment should be determined by considering the process, work equipment and the source of danger in the furniture manufacturing sector. The processes carried out and equipment in the joinery, paint shop and upholstery workshop contain many physical, chemical, ergonomic and biological risk factors.

One of the risk factors negatively affecting the health of employees during furniture manufacturing activities is wood dust. Longterm exposure to wood dust has been associated with a variety of adverse health effects, including dermatitis, allergic respiratory effects, mucosal and non-allergic respiratory effects and cancer. ${ }^{1}$ In studies conducted on these effects, wood dust appears to cause nasal and sinonasal cancers, lung cancer, asthma and chronic bronchitis. ${ }^{2-6}$ In addition, in 1995, the International Agency for Research on Cancer (IARC) listed wood dust in the Group I carcinogen list. The effects of wood dust vary according to the type of wood. Wood is classified as hard and soft wood. Generally, the harder the wood the more breakage occurs and the more dust it generates. ${ }^{7}$ In addition, classifications such as dry or moist wood were also made. For example, working with dry wood can produce a larger inhalable dust volume and a higher percentage of respirable dust particles. ${ }^{8}$ Wood dust is also generated when wood is cut, shaped, pressed, sanded and polished. Wood dust, according to its effect on employees, is grouped as respirable dust that can enter the head respiratory system and is deposited in the alveoli of the lung. ${ }^{9}$ Powder generally refers to solid particles ranging in size from 1 to $100 \mu \mathrm{m}$ measured in microns $(\mu \mathrm{m}) .{ }^{10}$ Since particles with a dust size of $<10 \mu \mathrm{m}$ settle veryslowly, they remain in polluted air for a long time and descend into the respiratory tract and lung alveoli. Respirable dust that accumulatesin the alveoli of the lung causes lung diseases. Therefore, dust of this size threaten the health of employees. ${ }^{11}$ The risks caused by the dust factor that threaten the health of the employee should be determined and necessary Occupational Health and Safety (OHS) measures should be taken. Wood dust exposure of employees should be evaluated by making workplace environment measurements and attention should be taken not to exceed national and international limit values by taking protection measures.

In 2002, the EU's Scientific Committee on Occupational Exposure Limits (SCOEL) stated that exposure to wood dust above 0.5 $\mathrm{mg} / \mathrm{m}^{3}$ causes lung diseases and should be avoided. ${ }^{12}$ The EU Directive (Council Directive 1999/38 / EC on the protection of workers from risks associated with exposure to carcinogens in the workplace and the extension to mutagens) sets a limit value of 5 $\mathrm{mg} / \mathrm{m}^{3}$ for respirable hardwood dust, but in 2002 this limit value was changed to $3 \mathrm{mg} /$ $\mathrm{m}^{3}$. According to the EU Directive (Directive (EU), 2017), exposure to hardwood dust remains at $3 \mathrm{mg} / \mathrm{m}^{3}$; however, this limit value will be reduced to $2 \mathrm{mg} / \mathrm{m}^{3}$ on 17 January 2023. ${ }^{13}$ Dust measurements can be taken in large wood industries compared to small businesses due to the adoption of OHS policy, institutionalization and the high number of employees. As a matter of fact, dust exposure 
rates have been investigated in large forest industries (sawmills, furniture factories, circular saws, sanding, etc.). ${ }^{14-16}$ In a study, it was emphasized that companies that developed a control system taking into account the legal process achieved more successful results in preventing the risks arising from wood dust. ${ }^{17}$ Small-scale furniture manufacturing enterprises are included in the scope of the legislation according to the number of employees. This situation causes control and prevention measures to be ignored in small-scale enterprises. In addition, due to the low number of employees and the fact that they operate as a family business, legal processes are not taken into account and a control system cannot be established. In dust analyses, personal exposure is determined bycomparing with the time weighted average (TWA) value. A study found that at least 22 million employees across Europe were exposed to IARC group 1 carcinogens, and thenumber of employees exposed to wood dust occupationally was 2.6 million. ${ }^{18}$ In our country, when the annual statistics of SGK 2010-2020 are examined, it is seen that the number of occupational diseases (from 4 to 5) in the field of furniture manufacturing does not tend to decrease. Occupational accidents and diseases are not reported in enterprises where the OHS policy is not applied, data entry cannot be made to the existing statistical sources. Therefore, research should be carried out to determine the current status of employees regarding dust exposure of such small-scale furniture manufacturing enterprises and necessary measures should be taken.

The aim of this study is to determine the respirable and inhalable dust exposure of the workers in small-scale furniture workshops located in Agri Organised Industrial Zone. For this purpose, the amount of dust exposed in the working environment was measured and the results were compared with the limit values in national and international legislation.

\section{MATERIALS AND METHODS}

'MDHS 14/3: Gravimetric analysis and sampling method of respirable and inhalable dust' was used in the study to determine respirable and inhalable dust exposure of employees in small-scale furniture workshops located in Agri Organised Industrial Zone.The gravimetric method is the collecting of dust on the filters by means of a suction pumpand dust collecting heads mounted on the worker which is then weighed on a precision scale and the weight of the collected dust is calculated. The weight of the collected dust in $\mathrm{mg}$ is divided by the volume of air absorbed

(L) during this time; it is then multiplied by $10^{3}$ and converted to $1 \rightarrow \mathrm{m}^{3}$, and the dust density is calculated as $\mathrm{mg} / \mathrm{m}^{3}$. For the dust measurement, the Buck Libra Pump Plus LP5 powder sampling pump and the primaryflow calibrator Sensidyne Gilian Gilibrator-2 were used. Air suction power (flow rate) of pumps can be adjusted to the desired level in the range. The flow rate used in this study wasset to 2.2 liter/minute for respirable dust sampling and 1.7 liter/ minute for inhalable dust sampling. Both before and after measurements of the flow rate of the pump were measured and the amount of deviation was determined. While taking the measurements, $37 \mathrm{~mm}$ PVC filters and filter holder cassettes were used for respirable dust measurements and $25 \mathrm{~mm}$ for inhalable dust measurements. The dust sampler was placed $30 \mathrm{~cm}$ from the breathing zone of the worker so that it would not interfere with his routine work and safety. ${ }^{19}$

Small-scale furniture workshops with less than 10 employees in Agri Organised Industrial Zone were selected and 5 workplaces agreed to participate in the study. A total of 22 people work in five workplaces. A total of 15 employees, 3 from each workshop, participated in the study. In the study, 30 respirable dust samples were obtained by measuring one-hour dust exposures for each worker in the morning and afternoon. In addition, with the same method, 
a total of 5 dust samples were taken, one for each workplace. Within the scope of the research, 35 samples were collected in the collection to determine respirable and total dust exposure. Based on these measurement results, a daily TWA was calculated for each employee according to the TS EN 689 standard. This standard gives the guidance for the assessment of exposure by inhalation to chemical agents for comparison with limit values measurement strategy. Limit values for powder density are determined based on the 8hour TWA. In this regard, the dust density was considered based on the TWA, not the individual measurement results. The wood dust concentration was calculated using the following formula:

$$
C={ }_{V}^{\underline{P_{2}}-P_{1}}
$$

where $\mathrm{C}$ is the wood dust concentration in $\mathrm{mg} / \mathrm{m}^{3}, \mathrm{P}_{2}$ is the weight of the filter in $\mathrm{mg}$ after testing, $\mathrm{P}_{1}$ is the weight of the filter in $\mathrm{mg}$ before sampling and $\mathrm{V}$ is the air volume in $\mathrm{m}^{3}$. The value of $\mathrm{V}$ in the equation is obtained by multiplying the duration of sampling in minutes $(\mathrm{T})$ and $(\mathrm{F})$ the air flow rate (in litres / minute) and dividing it by 1,000 . The F value is calculated by taking the average of the air flow rate values before and after measurement. Finally, the sampling data is expressed as an 8-hr TWA over study. In addition to these measurements, the measures taken against dust exposure during the measurements were checked using the Checklist for the Wood and Furniture Manufacturing Sector published by the ministry and the results are presented in the findings.

\section{Aspect of Research Ethics}

This study was supported by the MYO.19.003 code project by the Scientific and Technological Research Council of Ağn1 İbrahim Çeçen University (BAP). This scientific research Ağrı İbrahim Çeçen University Scientific Research Ethics Committee and the study was allowed with the decision dated 25.02.2021 and numbered 46.

\section{Conflict of Interest}

There was not any conflict of interest which was declared by the author.

\section{Limitation of Research}

The research was conducted in five workplaces in Ağrı. The limited number of furniture manufacturing workplaces in Ağrı is the limitation of the study

\section{Financial Disclosure}

This study was supported by the Scientific and Technological Research Council of Ağr1 İbrahim Çeçen University (BAP).

\section{RESULTS AND DISCUSSION}

Respirable and inhalable dust concentrations were measured at five workplaces. All of the workplaces are smallscale furniture workshops and the number of employees is less than 10 .

Measures taken for dust exposure, while taking measurements of the controls, were made using the Checklist for Wood and Furniture Manufacturing Sector published by the Ministry of Family, Labour and Social Services. It was observed that employees in the workplaces included in the study did not receive basic OHS training and did not use personal protective equipment (PPE) to prevent dust exposure in the work environment.

It was observed that only one of the workplaces has a dust extraction system in the machines used. Accordingly, information about the workplaces is presented in Table I. In the process of reporting the results, the name of each workplace is not used, but they are coded as W1, W2, W3, W4 and W5. 
GÜSBD 2021; 10(4): 740 - 750

\begin{tabular}{l} 
GUJHS 2021; 10(4): $740-750$ \\
\hline Table 1. Information on Workplaces
\end{tabular}
Gümüşhane Üniversitesi Sağlık Bilimleri Dergisi

Gümüşhane University Journal of Health Sciences
Araștırma Makalesi

Original Article

\begin{tabular}{lcccc} 
Workplace & $\begin{array}{c}\text { Number of } \\
\text { Employees }\end{array}$ & Dust extraction System & $\begin{array}{c}\text { PPE Use } \\
\text { Case }\end{array}$ & $\begin{array}{c}\text { Basic OHS } \\
\text { training status of } \\
\text { employees }\end{array}$ \\
\hline W1 & 5 & Yes & Yes & No \\
\hline W2 & 4 & No & No & No \\
\hline W3 & 4 & No & No & No \\
\hline W4 & 5 & No & No & No \\
\hline W5 & 4 & No & No & No
\end{tabular}

Respirable and inhalable dust concentrations made in small-scale furniture workshops were calculated using the formula

in Equation 1 and the results of exposure values are presented in Tables II for each workplace.

Table 2. Respirable Dust Concentration Exposure Value for Workplace

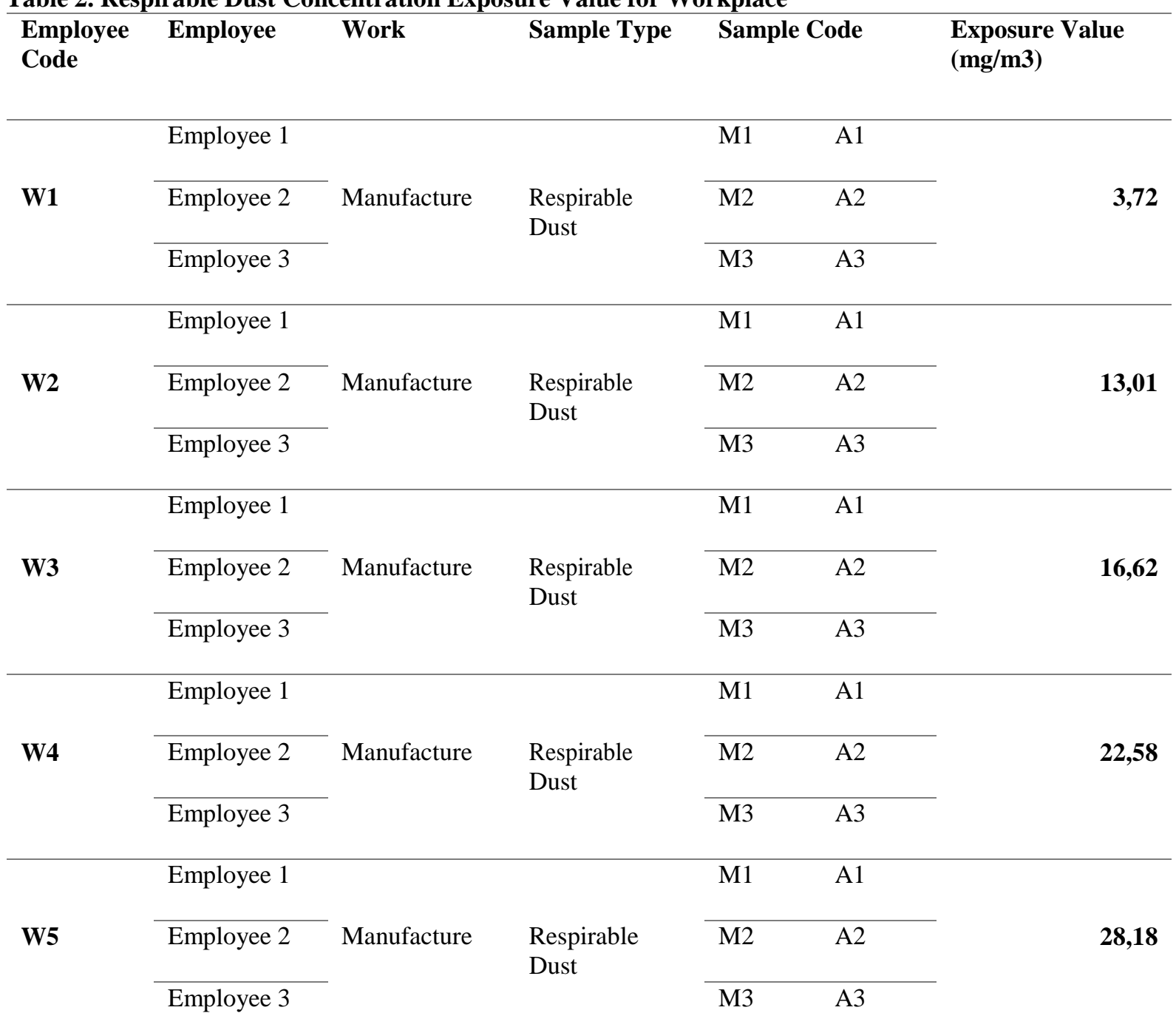

M: Morning measurement A: Afternoon measurement 
According to the measurement results, it was observed that the respirable dust concentration was the lowest in W1 $(3.72$ $\left.\mathrm{mg} / \mathrm{m}^{3}\right)$ and the highest in W5 $\left(28.18 \mathrm{mg} / \mathrm{m}^{3}\right)$. When the measures taken for dust exposure during the measurements were examined, it was seen that only one workplace took measures for ventilation and personal protective equipment. From this point of view, the presence of ventilation systems and the use of masks in $\mathrm{W} 1$ where precautions are taken can be considered as the reasons for thelow breathable exposure value. As a result of the measurements obtained from the workplaces, the inhalable dust concentration exposure values in the workplaces were calculated and are presentedin Table III.

Table 3. Inhalable Dust Concentration Exposure Values for Furniture Manufactures

\begin{tabular}{llll}
\hline Work & $\begin{array}{l}\text { Sample } \\
\text { Dust }\end{array}$ & $\begin{array}{l}\text { Workplace } \\
\text { Code }\end{array}$ & $\begin{array}{l}\text { Exposure } \\
\text { Value } \\
(\mathbf{m g} / \mathbf{m 3})\end{array}$ \\
\hline & $\mathrm{W} 1$ & 4,36 \\
\cline { 2 - 3 } & $\mathrm{W} 2$ & 11,62 \\
\hline Manufacture & $\mathrm{W} 3$ & 19,25 \\
\hline & $\mathrm{W} 4$ & 16,71 \\
InhalableDust & & 25,07
\end{tabular}

When the results of inhalable dust concentration are examined, it can be seen that the lowest value is in $\mathrm{W} 1\left(4.36 \mathrm{mg} / \mathrm{m}^{3}\right)$ and the highest value is in W5 $\left(25.07 \mathrm{mg} / \mathrm{m}^{3}\right)$. Similar to the respirable dust concentration results, it has been observed that the inhalable dust concentration value in the workplaces is lower than the other workplaces in $\mathrm{W} 1$ where precautions are taken to combat dust.

The accepted limit values for wood dust are expressed by different countries with different values. According to the wood dust content, it has been evaluated as hard and soft wood dust and separate limit values have been determined for both types of wood. Limit values for wood dust exposure are specified according to the 8-hour TWA (CFR 29.1910. 1000.Table Z, Health and Safety Administration (HSE) EH40 / 2005, 2018). Since the wood dust examined in our study is a type of hard wood dust, the limit value determined for hard wood dust was taken as the basis from the limit values where this distinction was made. Dust concentration exposure values in small-scale furniture workshops were compared with the national and international limit values presented in Table VI. 
Table 4. National and International Limit Values

\begin{tabular}{lcc}
\hline $\begin{array}{l}\text { National and international } \\
\text { legislation }\end{array}$ & \multicolumn{1}{c}{ Limit value } & For inhalable dust \\
\cline { 2 - 3 } & & \\
\hline $\begin{array}{l}\text { OSHA (Occupational Health } \\
\text { and Safety Administration, } \\
\text { USA) }\end{array}$ & $15 \mathrm{mg} / \mathrm{m}^{3}$ & \\
\hline $\begin{array}{l}\text { ACGIH (American Conference } \\
\text { of Governmental Industrial }\end{array}$ & & $1 \mathrm{mg} / \mathrm{m}^{3}$ \\
Hygienists) & & \\
\hline $\begin{array}{l}\text { HSE (Health and Safety } \\
\text { Administration, UK) }\end{array}$ & $3 \mathrm{mg} / \mathrm{m}^{3}$ \\
\hline $\begin{array}{l}\text { EC (European Commission } \\
\text { Document) }\end{array}$ & $5 \mathrm{mg} / \mathrm{m}^{3}$ \\
\hline $\begin{array}{l}\text { AIOH (Australian Institute of } \\
\text { Occupational Hygienists) }\end{array}$ & $5 \mathrm{mg} / \mathrm{m}^{3}$ \\
\hline $\begin{array}{l}\text { Legal legislation (Dust Control } \\
\text { Regulation) }\end{array}$ & \\
\hline
\end{tabular}

The obtained dust concentration exposure values are compared with national and international limit values and the results are shown in Figure 1 and Figure 2.

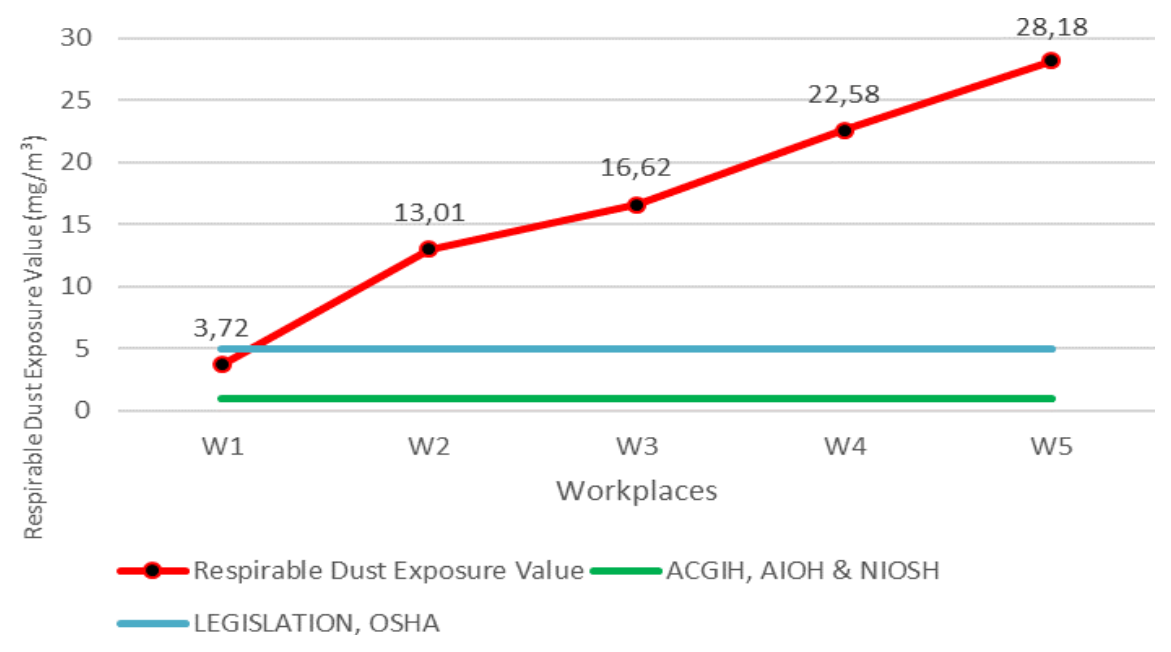

Figure 1. Comparison of Respirable Dust Exposure Values Measured at Workplaces with Limit Values

Figure. 1 shows the relationship between workplaces and respirable dust exposure $\left(\mathrm{mg} / \mathrm{m}^{3}\right)$ values in each workplace. As can be seen in the figure, the wood dust exposure value in $\mathrm{W} 1$ was the lowest, and the wood dust exposure value in W5 was the highest. When 
compared with the limit values, it can be seen that the respirable dust concentration exposure value calculated for $\mathrm{W} 1$ remained below the limit values specified in the legislation (dust regulation), OSHA, and remained above the limit values specified according to American Conference of Governmental Industrial Hygienists

\section{(ACGIH),}

Australian

Original Article Occupational Hygienists (AIOH) and HSE. It is seen that the exposure values for respirable dust concentrations calculated in other workplaces are above all limit values. 1,20-23 Figure 2 shows the relationship between the workplaces and the inhalable dust exposure $\left(\mathrm{mg} / \mathrm{m}^{3}\right)$ values in each workplace.

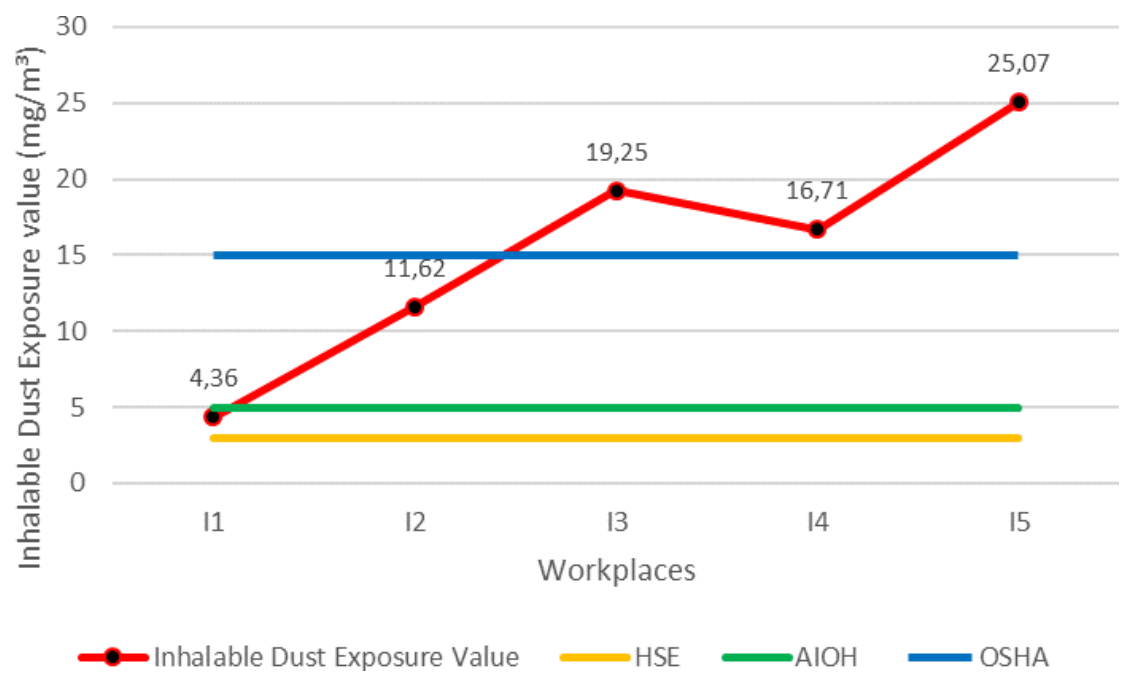

Figure 2. Comparison of Inhalable Dust Exposure Values Measured at Workplaces with Limit Values

When the exposure values of the inhalable dust concentration obtained are compared with the limit values, it is seen that the inhalable dust concentration exposure values calculated for $\mathrm{W} 1$ are below the limit values given according to AIOH, HSE and ACGIH, and the inhalable dust concentration for $\mathrm{W} 1$ is above the exposure value according to HSE. It was observed that the inhalable dust concentration exposure value calculated for W2 was above the limit values given according to AIOH and HSE, and below the limit value given according to OSHA. It is seen that the inhalable dust concentration exposure values calculated for $\mathrm{W} 3, \mathrm{~W} 4$ and W5 are above all limit values.

\section{CONCLUSION AND SUGGESTIONS}

There are pollutants in the form of gas, vapour, aerosol, dust, spray and smoke in the working air. Pneumoconiosis lung diseases can be seen as a result of long-term and high exposure to these pollutants in the working environment. The term pneumoconiosis is typically reserved for respiratory disease due to dust exposures, and it would be better to say that "Cancer, asthma and other respiratory diseases" may result from exposure to these pollutants. $2,7,5,24$

In our study, the results of respirable dust and inhalable dust measurements obtained from the small-scale furniture manufacturing sector were evaluated. As a result, it was concluded that the exposure values related to the dust concentration obtained from only one 
workplace are below the national and international limit values. During the controls performed during the environmental measurements, it was observed thatventilation and personal protective equipmentwere used only in one workplace to combat dust.

In our study, it was observed that the workplace with the lowest inhalable dust concentration exposure value was W1 (3.72 $\mathrm{mg} / \mathrm{m}^{3}$ ) and the highest value was found in W5 $\left(28.18 \mathrm{mg} / \mathrm{m}^{3}\right)$. In order to control dust exposure, effective local exhaust ventilation and appropriate personal protective equipment is needed. According to our study, within the scope of combating dust, both the lack of ventilation system and the exposure value in the workplace where personal protective equipment is not used have been found to be approximately 7.5 times higher. In addition, the lowest inhalable dust concentration exposure value was found in the workplace where dust-fighting measures were taken (W1: $4.36 \mathrm{mg} / \mathrm{m}^{3}$ ). The highest inhalable dust exposure value was found approximately six times higher in W5 without a ventilation system $\left(25.07 \mathrm{mg} / \mathrm{m}^{3}\right)$. Therefore, it is thought that control measures taken in combating dust will reduce dust exposure. As a matter of fact, it has been concluded that the dust exposure value is high in workplaces where there is no ventilation system within the scope of combating dust. ${ }^{25-}$ ${ }^{28}$ In another study, it was seen that the dust concentration in the working environment was higher than the limit values despite the ventilation system and it was concluded that the existing ventilation system did not work efficiently. ${ }^{29}$ As a result of the respirable and inhalable dust measurements we obtained from the small-scale furniture manufacturing workplaces with less than 10 employees, it has been observed that a large part of both respirable and inhalable dust exposure values in workplaces exceeded the limit values. In addition, as a result of the controls carried out in these workplaces, it was observed that they did not implement OHS services for combating dust. It is thought that the reason for this is that the study is carried out in smallscale enterprises. It is left to the initiative of employers and employees to take OHS precautions in working environments in small enterprises that have a low number of employees who work on their behalf. According to the Social Insurance Institution's 2019 statistics, it is stated that out of 21,758 people working in furniture manufacturing, 18,831 employees are employed in workplaces with less than 10 employees and 7,441 people are employed in workplaces with one employee Those who work on their behalf and on their own account without employing employees are excluded from the scope of the Law no. 6331 on Occupational Health and Safety. Therefore, in small-scale furniture manufacturing enterprises that do not employ employees, domestic labour is used and OHS measures are not taken. In addition, small-scale furniture manufacturing enterprises avoid taking precautions, as OHS measures are considered to be a financial burden on the employer. Therefore, practices and regulations such as tax reductions, incentives and projects that will contribute to the fight against dust in small-scale enterprises should be made. Engineering measures alone are not sufficient to combat dust. In addition, the efficiency of the system should be checked by performing periodic checks. ${ }^{30}$

Various occupational diseases occur as a result of exposure to wood dust in the furniture manufacturing sector. Wood dust, especially in respirable size, causes 
respiratory tract disorders, dermatitis symptoms, rhinitis and eye irritation, depending on the tree type and particle size. ${ }^{31}$ In order to prevent the risks that may arise from dust in the furniture manufacturing sector, it should be ensured that dust is struggled in terms of OHS and that the workers in these workplaces are protected from the effects of dust. One of these measures is workplace environment measurements. The dust exposure of the employees in the furniture manufacturing sector should be measured and necessary measures should be taken according to the measurement results.
Ventilation systems that are considered to be significantly effective in reducing dust exposure in workplaces need to be installed. As a matter of fact, in our study, the dust exposure value in the workplace with a ventilation system is lower than the values in other workplaces. Moreover, when we look at the results obtained in our study, it is seen that the value of exposure to dust in the workplace where the ventilation system is used is lower than the values in other workplaces. After the measurements taken at the source, attention should be paid to personal protection measures. Employers should ensure that masks that prevent dust exposure are used by employees.

\section{REFERENCE}

1. Occupational Safety and Health Administration (OSHA). (2021). "Woodworking e Tool". Access Address: https://www.osha.gov/SLTC/etools/wood working/production_wooddust.html\#Hazards/Solutions. (Date of access: 10.05.2021)

2. Alonso-Sardón, M, Chamorro, A.J, Hernández-García, I, Iglesias-de-Sena, H, Martín-Rodero, H, Herrera, C. and Mirón- Canelo, J.A. (2015). "Association between Occupational Exposure to Wood Dust and Cancer: A Systematic Review and Meta- Analysis”. PloS One, 10 (7), 1-16

3. Vallières, E, Pintos, J, Parent, M.E and Siemiatycki, J. (2015) "Occupational Exposure to Wood Dust and Risk of Lung Cancer in Two Population-Based Case-Control Studies in Montreal Canada". Environmental Health, 14 (1), 1-9.

4. Malo, J.L, and Cartier, A. (1989). "Occupational Asthma Caused By Exposure to Ash Wood Dust (Fraxinus Americana)". European Respiratory Journal, 2 (4), 385387.

5. Wiggans, R.E, Evans, G, Fishwick, D, and Barber, C.M. (2016). "Asthma in Furniture and Wood Processing Workers: A Systematic Review". Occupational Medicine, 66 (3), 193-201.

6. Enarson, D.A. and Yeung, M.C. (1999). "Characterization of Health Effects of Wood Dust Exposures". American Journal of Industrial Medicine, 17 (1), 33-38.

7. IARC. (1995). "Wood Dust and Formaldehyde. In Monographs on The Evaluation of The Carcinogenetic Risk of Chemicals To Humans". Access Address: https://publications.iarc.fr/Book- And-ReportSeries/Iarc-Monographs-On-The-Identification-OfCarcinogenic-Hazards-To-Humans/Wood-Dust-AndFormaldehyde-1995 (Date of access: 10 Oct 2020).

8. Hinds, W.C. (1988). "Basic for Size-Selective Sampling for Wood Dust". Applied Industrial Hygiene, 3 (3), $67-72$
9. ISO7708. (1995). "Air Quality: Particle Size Fraction Definitions for Health-Related Sampling," International Standards Organisation Publication. Access Address: https://www.iso.org /standard/14534.html. (Date of access: 5 Oct 2020)

10. Brown, J.S, Gordon, T, Price, O, and Asgharian, B (2013). "Thoracic and Respirable Particle Definitions For Human Health Risk Assessment". Particle and Fibre Toxicology, 10 (1), 1-12.

11. Mrackova, E, Kristak, L, Kucerka, M, Gaff, M, and Gajtanska, M. (2016). "Creation of Wood Dust During Wood Processing: Size Analysis, Dust Separation, and Occupational Health". BioResources, 11 (1), 209-222.

12. SCOEL. (2002). "Recommendation from the Scientific Committee on Occupational Exposure Limits" Access Address:https://ec.europa.eu/social/main.jsp?catId=148 \&langId=en\&intPageId=684. (Date of access: 19 Oct 2020).

13. Directive EU. (2017). "2017/2398 of the European Parliament and of the Council of 12 December 2017" Access Address: https://eur-lex.europa.eu/eli/dir/2017/ 2398/oj (Date of access: 10 Nov 2020).

14. Black, N, Dilwort, M, and Summer, N. (2017) "Occupational Exposure to Wood Dust in the British Woodworking Industry in 1999/2000". The Annals of Occupational Hygiene, 51 (3), 249260.

15. Horvat, D, Čavlović, A, Zečić, Ž, Šušnjar, M, Bešlić, I. and Madunić-Zečić, V. (2005). "Research of Fir-Wood Dust Concentration in the Working Environment of Cutters. Croatian Journal of Forest Engineering”. Journal for Theory and Application of Forestry Engineering, 26 (2), 85-90.

16. Marchi, E, Neri, F, Cambi, M, Laschi, A, Foderi, C, Sciarra, G. and Fabiano, F. (2017). "Analysis of Dust Exposure during Chainsaw Forest Operations". iForestBiogeosciences and Forestry, 10 (1), 341-347. 
17. Black, N, Dilwort, $M$. and Summer, N. (2017).'Occupational Exposure to Wood Dust in the British Woodworking Industry in 1999/2000". The Annals of Occupational Hygiene, 51 (3), 249-260.

18. Kauppinen, T, Toikkanen, J, Pedersen, D, Young, R, Ahrens, W, Boffetta, P. and Kogevinas, M. (2000). "Occupational Exposure to Carcinogens in the European Union". Occupational and Environmental Medicine, 57 (1), 10-18

19. HSE. (2000). MDHS14/3, "Methods for the Determination of Hazardous Substances. General Methods for Sampling and Analysis of Inhalable and Respirable Dust". Access Address: https://www.hse. gov.uk/acronym/ (Date of access: 19 Sep 2020).

20. AIOH. (2016). "Dust Not Otherwise Specified (Dust Nos) and Occupational Health Issues Position Paper" Australian Institute of Occupational Hygienists. Access Address: www.aioh. org.au/static/uploads/files/dustsnot-otherwise-specifiedand occupational-health-issueswfhzhxeesvwz.pdf (Date of access: 19 Nov 2020).

21. ACGIH. (2020). "Documentation of the Threshold Limit Values and Biological Exposure Indices" American Conference of Governmental Industrial Hygienists, Cincinnati. Access Address:https://www.acgih.org/about/volunteerleadersh ip/com mittees/ (Date of access: 2 Nov 2020).

22. HSE. (2012). "Toxic Woods. Wood Working Sheet No 30". Access Address: http://www.hse.gov.uk/ pUbns/wis30.pdf (Date of access: 5 Nov 2020).

23. Tozla Mücadele Yönetmeliği. (2013). Sayı: Mukerrer, 05/11/2013.

24. SCOEL. (2003). "Recommendation from The Scientific Committee on Occupational Exposure Limits: Risk Assessment for Wood Dust" SCOEL/SUM/102, Belgium,. Access Address: https://ec.europa.eu/social/ BlobServlet?docId=3876\&langId=en (Date of access: 5 Oct 2020)

25. Inthavong, K, Tian, Z. and Tu, J. (2009). "Effect of Ventilation Design on Removal of Particles in Woodturning Workstations". Building and Environment, 44 (1), 125-136.

26. Karakavak, A. (2014). "Talaşlı İmalat ve Kaynak İşlerinde Meslek İle İlgili Solunum Sistemi Hastalıklarının Önlenmesinde Endüstriyel Havalandırma. (Uzmanlık Tezi), ÇSGB, Ankara.

27. Mikkelsen, A.B, Schhlünssen, V, Sigsgaard, T. and Schaumburg, I. (2002). "Determinants of Wood Dust Exposure in the Danish Furniture Industry". Annals of Occupational Hygiene, 46 (8), 673-683.

28. Nor, MRBHM. (2014). "Effectiveness of Local Exhaust Ventilation Systems in Reducing Personal Exposure". Journal of Applied Sciences, 14 (13), 1365-1371.

29. SCOEL. (2003). "Recommendation from the Scientific Committee on Occupational Exposure Limits: Risk Assessment for Wood Dust" SCOEL/SUM/102, Belgium. Access Address: https://ec.europa.eu/social/ BlobServlet ?docId=3876\&langId=en (Date of access 21 Oct 2020).
30. HSE. (2012). "Toxic Woods. Wood Working Sheet No 30" Access Address: http://www.hse.gov.uk/pUbns/wis 30.pdf (Date of access 30 Nov 2020).

31. Kumar, V. (1988). Effectiveness of Local-Exhaust Ventilation for Drum-Filling Operations. Final Report (No. PB-89- 100226/XAB). PEI Associates, Inc., Cincinnati, OH (USA). Access Address: https://www. osti.gov/biblio/6620868. (Date of access 25 Oct 2020). 